\title{
Success Factors in Pepper Greenhouses - Case Study: Queretaro, Mexico
}

\author{
Judith Banda-Guzmán ${ }^{1} \&$ Alejandra López-Salazar ${ }^{2}$ \\ ${ }^{1}$ Department of Art \& Business, University of Guanajuato, Guanajuato, México \\ ${ }^{2}$ Department of Finance \& Administration, University of Guanajuato, Guanajuato, México \\ Correspondence: Alejandra López-Salazar, Department of Finance \& Administration, University of Guanajuato, \\ Guanajuato, México. Tel: 52-461-598-5922. E-mail: alelopez.salazar@yahoo.com
}

Received: March 27, 2014

Accepted: April 28, 2014

Online Published: May 5, 2014

doi:10.5430/ijba.v5n3p96

URL: http://dx.doi.org/10.5430/ijba.v5n3p96

\begin{abstract}
The purpose of this research is to analyze de success factors in pepper greenhouses. The research setting consists of eight pepper greenhouses in the state of Queretaro, Mexico. The research used the multiple-case contemporary method. In one of the eight cases, lack of success was found, as shown by three factors: financial management, staff retention and internationalization. In the other seven cases, seven factors were complied with satisfactorily, government subsidies being the exception. This paper also discusses the theoretical framework, conceptual details and conclusions reached.
\end{abstract}

Keywords: success factors, pepper greenhouses, case study, Mexico

\section{Introduction}

In Mexico SMEs make up $99 \%$ of companies, generating $72 \%$ of the employment in the country, and contributing $52 \%$ to the GNP (Gross National Product). SMEs are led by businesspersons who are educated at Bachelor's level in $38 \%$ of cases for males and $12 \%$ for females. There exists a lack of quality culture, as $86 \%$ of the companies have no certification at all. Only 17\% engage in exporting goods and services. There is a lack of technology use in their economic activities, staff is not qualified and government programs go unnoticed (Secretaría de Economía [SE], 2011). In terms of the SMEs working in the agriculture sector, in Mexico these are a very significant and productive sector in the country's economic, social and environmental development despite their low 3.8\% GNP contribution (INEGI, 2011). Their impact is much bigger than this percentage suggest, as most food products are produced in this sector, making it key in preserving food safety standards, life expenses and real income of the population; agriculture products are at the basis of a great number of industrial and commercial activities; agriculture is a fundamental activity in rural areas and in efforts to preserve natural resources in the face of climate change (FAO, 2009).

Some of the main problems encountered in developing agriculture activities are climate-change-induced losses (77.85\%), high costs of supplies and services (21.88\%), and lack of training and technical support (11.67\%). Other significant problems within this sector are hiring-period length, as $8 \%$ of staff is hired for over six months and $92 \%$ for fewer than six months, including $88 \%$ males and $12 \%$ females. $75 \%$ of producers only have primary schooling (INEGI, 2007).

Thus, in order to protect crops, preserve natural resources, make an efficient use of water and supplies, and meet the feeding needs of an increasing population, it is necessary for farmers, especially those in Queretaro, to use new agriculture production systems, and protected agriculture. The greenhouse is the most efficient technology to fight environmental hazards for best plant development results (Bastida, 2006). Better performance in a smaller space, and access to international markets with better prices are possible, thus offering safe, better-quality products at a lower cost. Crops can also be obtained outside their natural seasons, water can be saved, and diseased prevented (Barandiarán, 2009).

In this context, it is necessary for Mexican farmers to implement some measures to tackle the main existing problems for SMEs in the agriculture sector to guarantee their long-term survival (FAO, 2002). Rockart (1982:4) defined success factors as "those few key areas of activity in which favorable results are absolutely necessary for a particular manager to reach his or her goals". 
The objective of this article is to analyze the success factor of seven pepper greenhouses in the state of Queretaro, Mexico.

\section{Literature Review}

Success factors for SMEs have generally excluded the agriculture sector, seeing as there are few studies involving agriculture SMEs, particularly greenhouses, mostly focusing on technology (Denis, 2007; Hernández \& Castilla, 2000; Kipp, 2010), and on pepper plants (Urrestarazu, Castillo \& Salas, 2002; Gómez, Rodríguez, Enrique, Miranda \& González 2009), focusing on technical aspects of production.

In relation to studies conducted in other parts of the world on factors having a positive effect on SMEs, a case in point is Mahmood, Muhammad and Imran (2001) in Pakistan. Their results show that financial and technological resources, government support, market strategies and business skills such as leadership and decision-making, all have a positive impact on the success of the business. Their research showed that financial resources are the most important factor for the success of SMEs because these companies have scarce resources compared to big companies.

Additionally, Lussier and Halabi (2010) conducted a study into a sample of 131 unsuccessful companies and 103 successful ones in three different countries, namely, the United States, Croatia, and Chile. 15 key factors for success or failure were used, and their results show that companies that started with the right amount of capital, at a good economic time, keeping updated financial records and controls, developing specific plans, and seeking professional consultancy, can attract and retain quality staff, offer good products or services. Features of the businessperson such as a higher level of education, age, marketing skills, having businesspersons as parents, and years of management and industry experience are also factors increasing the chances of success.

Another study conducted in Spain by Aragón and Rubio (2005) into success factors in industrial SMEs found that the most important factors for success are having the right human resources management, innovation in products and services, technological resources, and having a flexible structure, where fewer hierarchical levels lead to greater freedom for workers to organize their work.

Bárcenas, Pérez and Trejo (2009) conducted a study in Mexico into factors affecting the success of SMEs using a sample of 405 Mexican companies. Their results showed that highly competitive companies are those that innovate their products, processes and management, using sophisticated technology and a strategic plan.

Another study conducted in the state of Veracruz by Aragón, García, Calvo-Flores, García and Madrid (2004) analyzed SMEs from different sectors, and found that the key success factors are developing new products and services, offering a lower price than the competitors, entering new markets, quality of product or service, flexible production and commercial processes, research and development efforts, technological processes revolving around flexible and innovative technologies, preparing and training staff, customer service, marketing, reputation and image efforts and skills. However, three factors that companies have valued as being the most important for their development and success are customer service, company reputation and image, and quality of product or service.

The studies discussed earlier reveal a range of factors that have a positive effect on the success of SMEs in sectors such as industry, services and commerce mainly. However, these studies exclude the agriculture sector. Some of the success factors identified in the literature of other countries and Mexico include the importance of having financial resources and training staff (Mahmood et al., 2011; Aragón et al., 2004); technological resources and quality of product or service (Mahmood et al., 2011; Aragón \& Rubio, 2005; Aragon et al., 2004; Gómez \& López, 2011), as well as the importance of business strategies (Mahmood et al., 2011; Lussier \& Halabi, 2010). However, there is a very particular set of problems affecting agriculture, which have to do with problems associated with climate conditions, and make it necessary to consider whether these factors are in line with the problems affecting agriculture SMEs.

Although many studies have identified some success factors, is necessary to deepen the study of success factors of pepper greenhouses, since studies have omitted factors that are of great importance for their development and survival as: retention of skilled labor, maintenance costs and quality certifications. Consider these factors are the main contribution of this work to the existing literature.

Some of the success factors identified by the Secretaria de Agricultura, Ganadería, Desarrollo Rural, Pesca $y$ Alimentación (2002) (Department of Animal Farming, Rural Development, Fishing, and Food) quoted by Food and Agriculture Organization of the United Nations [FAO] (2002) consider financial support (financial resources), 
technical support through technical and academic consultancy (consultancy), organization and the interests of the producers (alliances), capacity for innovation and improvement of existing proposals (technology), constant communication, continuity and commitment to the project (business skills), commercialization (market strategies), and agriculture climate conditions as factors that have a positive influence in the success of agriculture SMEs.

However, SAGARPA, only considers as relevant factors for success government support and fiscal subsidies as forms of government investment (Pennings, 2005, cited in Danielova \& Sarkar, 2011), quality of the pepper product, even though this might involve greater investment in the short term, not having any quality certificate reduces their capacity to export (Observatorio PyME, 2002), not considering internalization as a strategy to enter new markets, associated with better prospects of survival (Lee, Kelley, Lee, \& Lee, 2012).

The whole range of factors mentioned above are means to achieve success, which can be conceptualized in different forms, such as profitability, growth, survival, staff satisfaction, as well as customer satisfaction and personal satisfaction (Gorgievski, Ascalon \& Stephan, 2011). However, survival is considered as the most essential measure for the success of a company (Cowling, 2007, cited in Toledo, Jiménez \& Sánchez, 2012). In Mexico, the survival of SMEs depends on a 24-month period (Gómez \& Fernández, 2007). In the agriculture industry short-term growth or profit is not sought, but rather guaranteeing survival and improvement in the medium term (FAO, 2002). Thus, survival is a valid measure of the success of pepper greenhouses in the short term.

Having reviewed the literature, the following success factors have been considered in this study focusing on pepper greenhouses: k) businessperson profile, ii) government support, iii) financial management, iv) retention of qualified staff, v) product quality, vi) technological package, and vii) internationalization.

The first factor refers to the businessperson profile, which is related to identifying characteristics and skills managers or owners must have to attain their goals. According to recent studies, the number of years of experience in industry and the time spent managing the organization (Arasti, Zandi \& Talebi, 2012; Chawla, Khanna \& Chen, 2010; Islam, Aktaruzzaman \& Muhammad, 2011; Lussier \& Halabi, 2010; Newbert, Gopalakrishan \& Kirchhoff, 2008; Van Praag, 2003), the manager or owner's age can be positive in terms of maturity, but negative when the lifespan is reduced; in addition, older people may not be willing to adopt new technologies even when these can save energy and reduce operation costs (Bressler \& Edward, 2011), the level of education and training (Chawla, Pullig \& Alexander, 1997; Coy, Shipley, Omer \& Nisar, 2007; Lussier \& Halabi, 2010; Lussier \& Pfeifer,2001; Simpson, Tuck \& Bellamy, 2004) and the dedication and perseverance shown towards work (García, Crespo, Martí \& Crecente, 2007; Islam, Aktaruzzaman \& Muhammad, 2011) influence positively on the success of SMEs.

The second factors identified in the literature are government support and subsidies. SMEs play a crucial role in the economy of developed and developing countries, and the support policies in the form of subsidies have a positive influence in the growth of companies because they encourage these companies to invest in infrastructure and technological development to become more productive, and to generate poles of regional development (Cotti \& Skidmore, 2010; Resvani, Gilaninia, Mousavian \& Mohammad, 2011; Ríos \& García, 2011). In addition, fiscal reductions on subsidies or exemptions reduce the capital cost of the company, making these attractive products.

The third success factor refers to financial management. Several authors indicate that young companies starting with the required capital are less dependent on financing by others (González, Correa \& Acosta, 2012; Vivanco, Aguilera \& González, 2011), as they provide sufficient internal resources to pay their debts (González, Correa \& Acosta, 2012; Hussain, Millman \& Matlay, 2006; Sogorb, 2005; Silva \& Santos, 2002); they have enough capital to fund their operations (Aragón \& Rubio, 2005; Álvarez \& Abreu, 2008; González, Correa \& Acosta, 2012; García \& Martínez, 2007; Hussain, Millman \& Matlay, 2006; Lussier \& Halabi, 2010; Vivanco, Aguilera \& González, 2011), they have up-to-date detailed records to control their finances, and have better chances of success.

The fourth factor refers to qualified staff retention. In greenhouses, this plays a key role, as it represents $50 \%$ of their costs, and any decrease in workforce performance causes an immediate need for more staff (Manzano \& García, 2009). Authors like Lussier and Halabi (2010) in their study show that companies that cannot attract and retain their good employees have higher chances of failing, a situation that is aggravated in the case of SMEs, often due to poor or no human resource management (Arasti, Zandi, \& Talebi, 2012).

The fifth success factor is pepper product quality. This is related to the characteristics and attributes of the product and the needs and expectations of buyers. Authors such as Aragón and Rubio (2005) and Coy et al. (2007) consider that product quality is one of the most important factors for development and success. 
The sixth factor refers to the technological package. Mexico is undergoing a phase of transition from an agriculture-based model to a fully industrialized consumer-oriented society, which requires efforts, investments, and economic sacrifices (Arrioja, 2006). The adoption and use of new technologies have a positive relation on the development of businesses (Bressler, Bressler \& Edward, 2011; Caca, Cabej \& Xhuvani, 2010; Mahmood, Muhammad \& Imran 2011).

The last success factor identified is internationalization as way to achieve growth and survival through expansion of activities beyond national markets (Chelliah, Sulaiman \& Mohd, 2010; Hynes, 2010; H. Lee, Kelley, J. Lee \& S. Lee, 2012; Puerto, 2010) and that cooperation links can lead to internationalization.

\section{Method}

Seven success factors have been discussed, and the general hypothesis of this study can be formulated thus: The Businessperson Profile of Businessperson $P E$, established as a person with higher education studies, with professional experience in management, trained in different areas, and aged 30-40. The greenhouse has $A G$ government support and subsidies; it had $100 \%$ of the initial investment $I I$; manages to retain its workforce $M O$; produces pepper with the characteristics and attributes required by consumers $C P$; it has some kind of $T$ technology; exports $80 \%$ as export $E$; and it therefore is successful greenhouse company $E E$. Logically:

$$
\text { If } P E \cdot A G \cdot I I \cdot M O \cdot C P \cdot P T \cdot E \rightarrow E E
$$

This study has used the multiple-case contemporary method (Yin, 1994). Using eight cases and seven units of analysis within each case, an $8 \times 7$ matrix was obtained, what Yin (1994) calls a type 4, that is to say, more than one case and more than one variable of analysis, including a theoretical deductive method and an inductive one based on the cases.

In this study the seven multiple units that were analyzed were the businessperson profile, government support and subsidies, financial management, qualified staff retention, quality of the pepper product, technological package, and internationalization, that is, how these factors impacted in the success of the pepper greenhouses in the state of Queretaro.

The study revolved around eight cases of the eleven pepper greenhouses registered in the 2nd inventory of greenhouses held in 2009 in the state of Queretaro, in the municipalities of San Juan del Río, Corregidora, Huimilpan, and Pedro Escobedo (Secretaría de Desarrollo Agropecuario, 2010). The selection was made on the basis of those cases where participants willing to take part in the research were found.

For the data-collection process several techniques were used, amongst which was a semi-structured interview with the manager or owner as the key data source, using two common tools in all cases, which produced results that allowed comparisons to be made between cases. The interview increased the participation of the owner, and thus greater depth, quality, and detail of information were achieved (López, 2007). As far as direct observation was concerned, several greenhouses were visited to triangulate evidence obtained in the interview (it refers to verifying the data obtained from one source using other sources; in case studies each data item must be support with at least two sources), such as the technology used, their production processes, and details about the workforce.

To ensure the quality and objectivity of the research, three validity tests suggested by Ying (1994) were used, namely, validity of construct, external validity, and reliability. In the case of the validity of construct, multiple data sources were used (triangulation), establishing the chain of evidence, and reviewing the preliminary report on the case studies by key participant. As for external validity, the study establishes the domain in which the results of the study can be generalized, and sets the agenda for significant findings to be applied to other greenhouses in the region or state. Reliability shows to what extent other researchers with the same results can use the operations of the study, such as the data-collection methods. To this effect, data obtained through a questionnaire with managers or owners was recorded on file.

\section{Results and Characterization of Cases}

As shown below, there are strong similarities between cases, which make it possible to provide a general description of all the cases in relation to the seven success factors.

To interpret data, assuming each hypothesis is supported with the necessary data, each of the seven success factors was analyzed in relation to the eight greenhouses. Finally, a joint analysis was conducted for the seven factors to see if our general hypothesis holds. 


\subsection{Businessperson Profile}

Table 1. Businessperson profile

\begin{tabular}{|c|c|c|c|c|c|c|}
\hline Cases & Age & Gender & Training & Prior experience & $\begin{array}{c}\text { Mgmt. } \\
\text { experience }\end{array}$ & $\begin{array}{c}\text { Time spent } \\
\text { on the } \\
\text { greenhouse }\end{array}$ \\
\hline Hortalizas & 29 & $\mathrm{~F}$ & Foreign affairs & Logistics Dept. & 4 years & Full-time \\
\hline Bioproductos & 35 & M & $\begin{array}{l}\text { Mechanical } \\
\text { eng. }\end{array}$ & $\begin{array}{l}\text { Production } \\
\text { manager }\end{array}$ & 4 years & Full-time \\
\hline La Estancia & 57 & M & Agric. eng. & $\begin{array}{l}\text { Government } \\
\text { employee }\end{array}$ & 4 years & Part-time \\
\hline Doña Rosa & 46 & M & Agric. eng. & $\begin{array}{l}\text { Greenhouse } \\
\text { building }\end{array}$ & 7 years & Part-time \\
\hline La Llave & 47 & $\mathrm{~F}$ & $\begin{array}{l}\text { Chemistry } \\
\text { eng. }\end{array}$ & Laboratory & 4 years & Full-time \\
\hline La Lira & 52 & M & Agric. eng. & Agriculture & 7 years & Full-time \\
\hline Casa Blanca & 30 & M & Cooking & Cook & 7 years & Full-time \\
\hline $\begin{array}{l}\text { La Divina } \\
\text { Trinidad }\end{array}$ & 30 & M & Cooking & Cook & 4 years & Full-time \\
\hline
\end{tabular}

Table 1 provides the businessperson profile for each greenhouse, such as age, gender, training, prior experience, management experience and time spent on the greenhouse. Here we see that the age of managers ranges between 29 and 57. Most are male. In terms of education, in all eight cases the participants have higher education studies and think that greenhouse farming requires planning, execution, and follow-up to maintain good profits, and that knowledge acquired at university and training have had an impact in the good management of the greenhouse. None of the owners or managers had prior experience in this sector. The current experience in managing greenhouses in five cases is four years, and seven years in the remaining three cases. In most cases the time spent working on the greenhouse is full-time, except in two part-time cases.

\subsection{Government Support and Subsidies}

Table 2. Government support and VAT returns

\begin{tabular}{lllll}
\hline \multicolumn{1}{c}{ Company } & \multicolumn{1}{c}{$\begin{array}{c}\text { Source of } \\
\text { resources }\end{array}$} & Amount & $\begin{array}{c}\text { Resource } \\
\text { allocation }\end{array}$ & VAT returns \\
\hline Hortalizas & $\begin{array}{l}\text { Federal support } \\
\text { Federal support }\end{array}$ & $\begin{array}{l}\$ 743,000 \\
\$ 1^{\prime} 250,000\end{array}$ & $\begin{array}{l}\text { Infrastructure } \\
7560 \mathrm{mt} 2 \text { expansion }\end{array}$ & $\begin{array}{c}\text { Applied for every } \\
\text { six months }\end{array}$ \\
Bioproductos & State support & $\$ 700,000$ & Infrastructure & Not applied for \\
La Estancia & State support & $\$ 200,000$ & Heating & Not applied for \\
Doña Rosa & No support & & & Not applied for \\
La Llave & State support & $\$ 600,000$ & Infrastructure & Not applied for \\
La Lira & Federal support & $\$ 800,000$ & Infrastructure & Not applied for \\
& State support & $\$ 500,000$ & Infrastructure & Not applied for \\
Casa Blanca & State support & $\$ 200,000$ & Heating & Not applied for \\
La Divina Trinidad & State support & $\$ 700,000$ & Infrastructure & Heating \\
\hline
\end{tabular}

Note: All amounts in Mexican pesos (MXN)

Table 2 outlines government support and VAT returns considering the source of resources, amount of resources, resources allocation and VAT returns. The funds received came mostly from Secretaria de Desarrollo Agropecuario del Estado de Querétaro (SEDEA) (Farming Development Department of the State of Queretaro) and federal funds in two cases coming from the Fideicomiso de Riesgo Compartido (FIRCO) (Joint-Risk Trust). Funds were used to build the greenhouse in seven cases, and only in the cases of La Lira, Casa Blanca and La Divina additional funding were used to buy heating equipment. Even though heating is not needed all the time, it protects crops in the event of frost, preventing large losses, and it extends the harvesting well into winter, thus reaching better prices in the markets. 
In seven cases there is no knowledge of the exemptions or subsidies available to their companies, as they think they are not required to pay taxes because their economic sector is privileged, and only in one case VAT returns are applied for.

\subsection{Financial Management}

Table 3. Financial management

\begin{tabular}{llccrc}
\hline Case & Company & Profitability & Debt index & Mt2 & Kg x mt2 \\
& & & & & \\
\hline 1 & Hortalizas & $29 \%$ & $55 \%$ & 12,744 & $15 \mathrm{~kg}$ \\
2 & Bioproductos & $27 \%$ & $30 \%$ & 5,140 & $16 \mathrm{~kg}$ \\
3 & La Estancia & $10 \%$ & $10 \%$ & 2,000 & $13 \mathrm{~kg}$ \\
4 & Doña Rosa & $25 \%$ & $0 \%$ & 5,000 & $14 \mathrm{~kg}$ \\
5 & La Llave & $27 \%$ & $33 \%$ & 12,000 & $15 \mathrm{~kg}$ \\
6 & La Lira & $30 \%$ & $30 \%$ & 10,000 & $16 \mathrm{~kg}$ \\
7 & Casa Blanca & $20 \%$ & $0 \%$ & 5,000 & $14 \mathrm{~kg}$ \\
8 & La Divina Trinidad & $20 \%$ & $0 \%$ & 12,500 & $14 \mathrm{~kg}$ \\
\hline
\end{tabular}

Table 3 reports financial management including profitability, debt index, square metre and kilogram per square metre. One of the reasons for growing peppers in greenhouses is the profit margin created to pay back for loans; in the first Hortalizas case a yield of $15 \mathrm{~kg} \mathrm{x} \mathrm{mt} 2$ produced a net profit of $29 \%$; Bioproductos, despite its a greenhouse growing crops in the ground, achieved a better performance than the hydroponics greenhouse under the supervision of a technician over the daily tasks of staff, producing $16 \mathrm{~kg} \mathrm{x} \mathrm{mt} 2$ and a $27 \%$ net profit in the cycle; La Llave had yields of $15 \mathrm{~kg} \mathrm{x} \mathrm{mt2}$, and a net profit of $27 \%$; La Lira produced $16 \mathrm{~kg} \mathrm{x} \mathrm{mt2,} \mathrm{and} \mathrm{had} \mathrm{a} 30 \%$ net profit. In all four cases a high level of debt can be observed especially at the start; however, these are the four cases with the best profits and yields by $\mathrm{mt}$. The La Estancia case is the least profitable, for various reasons, as this is the smallest greenhouse with fixed labor costs similar to those of a greenhouse twice its size. The owner comments that the staffs do not complete the essential tasks in time, which restrict greater profits.

\subsection{Qualified Staff Retention}

Table 4. Employees and turnover

\begin{tabular}{|c|c|c|c|c|}
\hline Case & Company & Employees & Turnover & Non-paid perks \\
\hline 1 & Hortalizas & $\begin{array}{l}8 \text { women } \\
2 \text { men }\end{array}$ & No & $\begin{array}{l}\text { Flexible working hours } \\
\text { Paid leave }\end{array}$ \\
\hline 2 & Bioproductos & $\begin{array}{l}4 \text { women } \\
1 \text { man }\end{array}$ & No & $\begin{array}{l}\text { Flexible working hours } \\
\text { Paid leave }\end{array}$ \\
\hline 3 & La Estancia & $\begin{array}{l}4 \text { women } \\
2 \text { men }\end{array}$ & No & $\begin{array}{l}\text { Flexible working hours } \\
\text { Paid leave }\end{array}$ \\
\hline 4 & Doña Rosa & $\begin{array}{l}4 \text { women } \\
1 \text { man }\end{array}$ & No & $\begin{array}{l}\text { Flexible working hours } \\
\text { Paid leave }\end{array}$ \\
\hline 5 & La Llave & $\begin{array}{l}6 \text { women } \\
4 \text { men }\end{array}$ & Yes & $\begin{array}{l}\text { Flexible working hours } \\
\text { Paid leave }\end{array}$ \\
\hline 6 & La Lira & $\begin{array}{l}8 \text { women } \\
2 \text { men }\end{array}$ & No & $\begin{array}{l}\text { Flexible working hours } \\
\text { Paid leave }\end{array}$ \\
\hline 7 & Casa Blanca & 2 women & No & $\begin{array}{l}\text { Flexible working hours } \\
\text { Paid leave }\end{array}$ \\
\hline 8 & La Divina Trinidad & $\begin{array}{l}7 \text { men } \\
2 \text { women }\end{array}$ & Yes & $\begin{array}{l}\text { Flexible working hours } \\
\text { Paid leave }\end{array}$ \\
\hline
\end{tabular}

In Table 4 we present number of employees, turnover and non-monetary benefits. At the close of the 2012 cycle, Hortalizas had ten employees for farming tasks, eight women and men, the latter to do maintenance work; Bioproductos had five employees, four women and one man; La Estancia, six, four women and two men; Doña Rosa, five, four women and one man; La Llave, ten, eight men and two women; La Lira, ten, eight women and two men; 
Casa Blanca, two women; La Divina Trinidad, nine, two men and seven women. One of the important findings is connected to the kind of people doing daily jobs in the greenhouse; in cases with no turnover, the employees are mostly women, and in the Casa Blanca case, most are men; additionally, staff are temporarily laid off at the end of each cycle; which makes it hard to re-employ them when the new cycle starts. Lack of qualified staff also affected the yield in the last cycle. As for the other seven greenhouses, they do not lay off their employees at the end of the cycle; instead, they are employed on a permanent basis. In all cases, staff have non-paid perks such as flexible hours and paid leave.

4.5 Pepper Product Quality

Table 5. Pepper product quality

\begin{tabular}{|c|c|c|c|c|}
\hline Case & Company & Certified & Certification type & Certification body \\
\hline 1 & Hortalizas & No & $\begin{array}{l}\text { Certification in } \\
\text { process }\end{array}$ & Cesaveg \\
\hline 2 & Bioproductos & Yes & $\begin{array}{l}\text { Health, BPA and } \\
\text { Organic }\end{array}$ & $\begin{array}{l}\text { Cesaveg } \\
\text { Primus Lab }\end{array}$ \\
\hline 3 & La Estancia & No & None & None \\
\hline 4 & Doña Rosa & Yes & $\begin{array}{l}\text { Health, BPA and } \\
\text { Organic }\end{array}$ & $\begin{array}{l}\text { Cesaveg } \\
\text { Primus Lab }\end{array}$ \\
\hline 5 & La Llave & Yes & $\begin{array}{l}\text { Health, BPA and } \\
\text { Organic }\end{array}$ & $\begin{array}{l}\text { Cesaveg } \\
\text { Primus Lab }\end{array}$ \\
\hline 6 & La Lira & Yes & $\begin{array}{l}\text { Health, BPA and } \\
\text { Organic }\end{array}$ & $\begin{array}{l}\text { Cesaveg } \\
\text { Primus Lab }\end{array}$ \\
\hline 7 & Casa Blanca & Yes & $\begin{array}{l}\text { Health, BPA and } \\
\text { Organic }\end{array}$ & $\begin{array}{l}\text { Cesaveg } \\
\text { Primus Lab }\end{array}$ \\
\hline 8 & La Divina Trinidad & Yes & $\begin{array}{l}\text { Health, BPA and } \\
\text { Organic }\end{array}$ & $\begin{array}{l}\text { Cesaveg } \\
\text { Primus Lab }\end{array}$ \\
\hline
\end{tabular}

Table 5 shows pepper product quality through certified type and certification body. Hortalizas and La Estancia do not have any kind of certification at the moment; however, they have identified the attributes their peppers must possess for packers to choose their produce for export. Hortalizas, unlike La Estancia, despite its not having a certification, does what is needed in terms of care taken to produce clean pepper featuring the right physical properties and expected yields as a result of the direct supervision of the manager or owner. At La Estancia their produce does not always meet the size and firmness characteristics required because the manager is not working there full-time. This results in lack of commitment in staff, unwilling to the daily tasks adequately to achieve the required standards of quality.

\subsection{Technological Package}

Table 6. Type of technology

\begin{tabular}{clccc}
\hline Case & Company & $\begin{array}{c}\text { Type of } \\
\text { technology }\end{array}$ & Farming type & $\begin{array}{c}\text { Yield in kg x } \\
\text { mt2 }\end{array}$ \\
\hline 1 & Santa Teresa & Average & Hydroponics & $15 \mathrm{Kg}$ \\
2 & Bioproductos & Average/Low & Ground & $16 \mathrm{Kg}$ \\
3 & La Estancia & Low & Ground & $13 \mathrm{Kg}$ \\
4 & Doña Rosa & Average & Ground & $14 \mathrm{Kg}$ \\
5 & La Llave & Average/Low & Ground & $15 \mathrm{Kg}$ \\
6 & La Lira & Average & Ground & $16 \mathrm{Kg}$ \\
7 & Casa Blanca & Average & Ground & $14 \mathrm{Kg}$ \\
8 & La Divina Trinidad & Average & Ground & $14 \mathrm{Kg}$ \\
\hline
\end{tabular}

Table 6 outlines technological package such as type of technology, farming type and yield in kilograms per square metre. In relation to the different extras added to greenhouses the kind of technology used in most of them is average, 
except for Bioproductos and La Llave, where they combine average with low technology. In addition, the type of technology can be compared to the yields obtained by $\mathrm{mt} 2$, and the results show that technology was not a key factor in terms of increased yields in greenhouses, as Hortalizas had a yield of $15 \mathrm{~kg} \mathrm{x} \mathrm{mt2} \mathrm{and} \mathrm{La} \mathrm{Lira,} 16 \mathrm{~kg} \mathrm{x} \mathrm{mt2,} \mathrm{both}$ using similar technologies. The difference might be linked to the number of years of experience in this sector, Hortalizas being four years old and La Lira, seven. In contrast, Bioproductos had a yield of $16 \mathrm{~kg} \mathrm{x} \mathrm{mt} 2$ and La Llave, $15 \mathrm{~kg} \mathrm{x} \mathrm{mt2,} \mathrm{both} \mathrm{using} \mathrm{a} \mathrm{system} \mathrm{of} \mathrm{ground} \mathrm{crops,} \mathrm{one} \mathrm{of} \mathrm{them} \mathrm{using} \mathrm{manual} \mathrm{irrigation} \mathrm{and} \mathrm{the} \mathrm{other,} \mathrm{automatized,}$ but both achieving similar yields in their average-technology greenhouses. The system in all cases is ground crops, except in the case of Hortalizas Santa Teresa, which uses hydroponics and volcanic rock as a substratum.

\subsection{Internationalization}

Table 7. Internationalization

\begin{tabular}{|c|c|c|c|c|}
\hline Case & Company & Exports? & Exports to & Intermediary \\
\hline 1 & Hortalizas & Yes & $\begin{array}{l}\text { United States and } \\
\text { Canada }\end{array}$ & $\begin{array}{l}\text { Comercializadora } \\
\text { Silao, Gto. }\end{array}$ \\
\hline 2 & Bioproductos & Yes & United States & Empaque-INUNI \\
\hline 3 & La Estancia & Yes & $\begin{array}{l}\text { United States and } \\
\text { Canada }\end{array}$ & $\begin{array}{l}\text { Comercializadora } \\
\text { Colón, Querétaro. }\end{array}$ \\
\hline 4 & Doña Rosa & Yes & United States & Empaque-INUNI \\
\hline 5 & La Llave & Yes & United States & $\begin{array}{l}\text { Comercializadora } \\
\text { Celaya, Gto. }\end{array}$ \\
\hline 6 & La Lira & Yes & United States & Empaque-INUNI \\
\hline 7 & Casa Blanca & Yes & United States & Empaque-INUNI \\
\hline 8 & $\begin{array}{l}\text { La Divina } \\
\text { Trinidad }\end{array}$ & Yes & United States & Empaque-INUNI \\
\hline
\end{tabular}

In Table 7 we present the degree of internationalization, specifically exportation, country to which it export and the intermediary company. From the options available to export, Bioproductos, Doña Rosa, La Lira, Casa Blanca and La Divina Trinidad greenhouses have a cooperation agreement to create their own packing service (INUNI), despite being competitors. This implies sharing fixed costs incurred in shipping, logistics and sales. In La Estancia case, a company in Colón, Queretaro, packs their peppers; Hortalizas sales through a packing company in Silao, Guanajuato, and La Llave uses a company in Celaya, Guanajuato.

4.8 Successful and Less Successful Greenhouses

Table 8. Successful and less successful greenhouses in relation to the success factors

\begin{tabular}{clcccccccc}
\hline Case & Company & BP & SU & FM & QSR & PQ & TP & INT & Total \\
\hline 1 & Hortalizas & C & C & C & C & C & C & C & 7 \\
2 & Bioproductos & C & NC & C & C & C & C & C & 6 \\
3 & La Estancia & NC & NC & C & C & NC & NC & C & 3 \\
4 & Doña Rosa & C & NC & C & C & C & C & C & 6 \\
5 & La Llave & C & NC & C & NC & C & C & C & 5 \\
6 & La Lira & C & NC & C & C & C & C & C & 6 \\
7 & Casa Blanca & C & NC & C & C & C & C & C & 6 \\
8 & La Divina & C & NC & C & NC & C & C & C & 5 \\
& Total & 7 & 1 & 8 & 6 & 7 & 7 & 8 & \\
\hline
\end{tabular}

To interpret this data, starting from the assumption that each hypotheses is linked to the necessary supporting evidence, each of the seven hypotheses presented for the eight greenhouses was analyzed, and Table 8 shows the summary of the seven success factors to assess the validity of the overall hypothesis. Of the eight cases, Hortalizas complies with all the seven success factors; Bioproductos, Doña Rosa, La Lira, and Casa Blanca comply with six of seven factors, which makes them successful greenhouses; La Llave and La Divina, five of seven are moderately successful and La Estancia only complied with three factos, and has thus been classified as being less successful. 
Our general hypothesis states that if the seven factors are complied with the greenhouses can be considered successful. Therefore, pepper greenhouses that have remained in the market for over 24 months can be said to have survived and thus be called successful.

Table 9. Successful greenhouses

\begin{tabular}{llc}
\hline Case & \multicolumn{1}{c}{ Company } & $\begin{array}{c}\text { Years of } \\
\text { operation }\end{array}$ \\
\hline 1 & Hortalizas & 4 years \\
2 & Bioproductos & 4 years \\
3 & La Estancia & 4 years \\
4 & Doña Rosa & 7 years \\
5 & La Llave & 4 years \\
6 & La Lira & 7 years \\
7 & Casa Blanca & 7 years \\
8 & La Divina & 4 years \\
\hline
\end{tabular}

Table 9 reports successful greenhouses through years of operation. The eight cases have survived for over 24 months ( 2 years), and have therefore complied with most of the seven success factors. We can therefore say that the eight greenhouses have been successful for having passed the two-year survival barrier, whereas $70 \%$ do not usually achieve this kind of success (SE, 2011)

\section{Conclusions}

The main problem in Mexican agriculture is climate-induced losses (77.85\%), and losses caused by ground fertility issues (24.81\%) (INEGI, 2007), both of which can be overcome using greenhouses. Protecting the crops produces greater yields. In addition, using average technology, the cases in this study showed success rates in terms of production and growth of land for crops.

INEGI (2007) reported a level of education in Mexico of primary school in $75 \%$ of farmers and established that $11.67 \%$ lacks training and technical assistance. In the eight cases of this study, they had higher education studies and were trained, especially in greenhouse farming. Additionally, in six of the eight cases, the businessperson worked full-time in the greenhouse, managing and operating it.

The eight cases were successful because their financial management was efficient and had sufficient initial investments to buy the greenhouse technology, as well as the funds to pay for the work that produced the first harvest. This tended to be self-financed or financed by a financial institution. This stands in contrast with the debts or lack of access to loans typically reported in this sector (INEGI, 2007).

In addition to the initial investment, the producers referred to government subsidies, which encouraged their investment in this sector (Pennings, 2005, cited in Danielova and Sarkar, 2011). In seven of the eight cases of success, they had access to some sot of direct subsidy from the State of Queretaro or Federal bodies. However, only one case had tax planning in place to secure VAT returns.

Mexican agriculture lacks qualified staff because $92 \%$ of staff is hired for periods under six months, $88 \%$ of whom are men and 12\%, women (INEGI, 2007). This problem has been almost completely solved because in six of the eight cases managed to retain qualified staff permanently for the whole year and women had a more significant participation in the workforce. Greater flexibility of work hours contributed to improving the quality of life of both the workers and their families.

Another problem affecting Mexican agricultures is the lack of a culture of quality, as $86 \%$ have no certification (SE, 2011). In the current globalized world, quality standards are key, as are Food safety management systems ((FSMS), as the main aim is to protect public health and promote equal opportunities in the food markets. This can be achieved by complying with the Codex Alimentarius Committee, as this can help member states to take decisions on regulations issues to facilitate international food trade by promoting harmonized national regulations (FAO, 2002). Six of the eight cases have been certified for their good agricultural practices and one is in the process of becoming certified.

Certifications have an impact on opportunities to enter international markets (Agus y Hassan, 2011), especially in the case of pepper exports. In all eight cases, they export $80 \%$ of their production to the United States through cooperation agreements with other producers and with packing or sales companies. This goes against the assumption 
that Mexican produce is hardly sold in other countries suggested by the $17 \%$ rate of participation of SMEs in exports of goods and services (SE, 2011).

Success factors for greenhouses were identified on the basis of problems affecting Mexican agriculture and considering models tested in other countries, such as in Pakistan (Mahmood, Muhammad \& Imran, 2011), where financial resources, technology, government support, market strategies, and business skills such as leadership and decision-making have a positive and significant impact on the success of the business. However, this model does not consider some important factors for pepper greenhouses, key to their survival, such as qualified staff retention, as the latter absorbs $50 \%$ of the fixed costs of the companies; losing staff increased the need for staff, and some tasks require certain specialized skills (Manzano \& García, 2009), the quality of peppers, and internationalization, as said above, have an impact too, as do having a quality certification, without which export opportunities are dramatically reduced, as are survival chances (Lee, Kelley, Lee, \& Lee, 2012).

Aragón, García, Calvo-Flores, García and Madrid (2004) suggested that the most important success factors were financial capabilities, technological position, innovation, human resources management, marketing capabilities, and information and communication technologies. This model rejects factors such as government support and subsidies to support companies that lack technology and equipment, pepper product quality, which even though it involves a bigger investment in the short term is necessary to seek internationalization, not having quality certifications, which reduces chances of exporting (Vivanco, Aguilera, \& González, Desarrollo de las Pymes con base en la Adopción de Estrategias Financieras en Aguascalientes, 2011). Similarly, the businessperson profile was not considered as a success factor, the focus being limited to only education levels.

On the basis of problems affecting agriculture in Mexico identified in INEGI (2007), and on the models identified in the literature, a new model was created to fit the eight cases in this sector, which resulted in a set of seven success factors: Businessperson profile, government support and subsidies, financial management, qualified staff retention, product quality, technological package, and internationalization.

The multiple-case study used in our work, as methodology, was appropriate to identify the success factors for greenhouses, due to the lack of adequate databases to embrace all the aspects related to the companies, especially in the agriculture sector. In the case of Mexico, despite having institution such as INEGI to gather statistical data, the chances of analysis are still limited, considering the fast-paced changes that make data out of date easily, as is the case with the last available data coming from 2007. In addition, the case study method allowed us to come into contact with the object of study thus opening up new interpretations on company features (Fong, 2008).

Finally, there are limitations to this study, such as including pepper greenhouses from one state only, allowing only generalizing for greenhouses in the state of Queretaro; tomato, cucumber and other crops grown in greenhouses were also left out and should become the focus of future studies.

\section{References}

Álvarez, M., \& Abreu, J. (2008). Estrategias Financieras en la Pequeña y Mediana Empresa. International Journal of Good Conscience, 3(2), 65-104.

Aragón, A., \& Rubio, A. (2005). Factores Asociados con Éxito Competitivo de las PyMEs Industriales en España. Universia Business Review, 8, cuarto trimestre, 38-51.

Arasti, Z., Zandi, F., \& Talebi, K. (2012). Exploring the Efect of Individual Factors on Business Failure in Iranian New Established Small Business. International Business Research, 5(4), 2-11. $\mathrm{http}: / /$ dx.doi.org.10.5539/ibr.v5n4p2

Arrioja, A. (2006). Derecho Fiscal. México: Themis.

Barandiarán, N. (2009). Agricultura protegida, gran oportunidad. Retrieved October 17, 2011, from

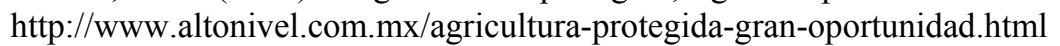

Bastida, A. (2006). Manejo y Operación de Invernaderos Agricolas. México: Serie de Publicaciones Agribot.

Bressler, M., Bressler, L., \& Edward., B. (2011). A Study of Small Business Technology Adoption and Utilization. Academy of Entrepeneurship Journal, 17(2), 49-60.

Caca, E., Cabej, E., \& Xhuvani, A. (2010). The Role of Innovation and Technology to SMES Development (Albania Case). The Young Economist Journal, 9(17), 141-149.

Chawla, S., Khanna, D., \& Chen, J. (2010). Are Small Business Critical Success Factors Same in Different Countries? SIES Journal of Management, 7(1), 1-12. 
Chawla, S., Pullig, C., \& Alexander, D. (1997). Critical Success Factors from an Organizational Life Cycle Perspective: Perceptions of Small Business Owner from Different Business Environments. Journal of Business and Entrepeneurship, 9(1), 47-58.

Chelliah, S., sulaiman, M., \& Mohd, Y. (2010). Internationalization and Performance: Small and Medium Enterprises in Malaysia. International Journal of Business and Management, 5(6), 27-37.

Cotti, C., \& Skidmore, M. (2010). 1980-2007, The Impact of State Government Subsidies and Tax Credits in an Emerging Industry: Ethanol Production. Souther Economic Journal, 76(4), 1076-1093. http://dx.doi.org/10.4284/sej.2010.76.4.1076

Coy, S., Shipley, M., Omer, K., \& Nisar, R. (2007). Factors Contributory to Success: A Study of Pakistan's Small Business Owners. Journal of Developmental Entrepeneurship, 12(02), 181-198. http://dx.doi.org/10.1142/S1084946707000617

Dennis, R. (2007). La Tecnología de Invernadero en el Valle del Yaqui. Una Alternativa para el Desarrollo Regional. Octavo Congreso Nacional y Cuarto Congreso Internacional de la Red de Investigación y Docencia sobre Innovación.

FAO. (2002). Calidad y Competitividad de la Agroindustria Rural de América Latina y el Caribe.

FAOSTAT. (2010). Retrieved October 20, 2011, from http://faostat.fao.org/

Gallardo, M. (2005). Métodos de Control de Riego en Cultivos en Sustrato. Horticultura, 183, 26-31.

García, A., Crespo, J. L., Martí, F., \& Crecente, F. (Mayo de 2007). Perfil de los Empresarios y Resultados de sus Empresas. Documento de trabajo 05/2007, Instituto Universitario de Análsis Económico y Social, Universidad de Alcalá., 1-30. Retrieved June 21, 2012, from http://dspace.uah.es/dspace/bitstream/handle/10017/6523/perfil_garcia_IAESDT_2007.pdf?sequence=1

García, P. J., \& Martínez, P. (2007). Effects of Working Capital Management of SME Profitability. International Journal of Managerial Finance, 3(April), 164-177. http://dx.doi.org/ 10.1108/17439130710738718

Gómez, L., Rodríguez, M. G., Enrique, R., Miranda, I., \& González, E. (2009). Factores Limitantes de los Rendimientos y Calidad de las Cosechas en la Producción Protegida de Hortalizas en Cuba. Revista Protección Vegetal, 24(2), 117-122.

González, A. L., Correa, A., \& Miguel., A. (2000). Fuentes de Rentabilidad en la Pyme Canaria. Canaria.

Gorgievski, M. J., Ascalon, M. E., \& Stephan, U. (2011). Small Business Owners Success Criteria, Approach to Personal Differences. Journal of Small Business Management, 49(2), 207-232. http://dx.doi.org/10.1111/j.1540-627X.2011.00322.x

Hussain, J., Millman, \& Harry, M. (2006). SME Financing in the UK and in China: a Comparative Perspective. Journal of Small Business and Enterprise, 13(4), 584-599. http://dx.doi.org/10.1108/14626000610705769

Hynes, B. (2010). International Small Business Growth: A Process Perspective. The Irish Journal of Management, 29(2), 87-103.

INEGI. (2009). Información Económica de Coyontura.

INEGI. (2007). Censo Agrícola, Ganadero y Forestal.

INEGI. (2004). Censos Económicos.

Islam, A., Aktaruzzaman, M., \& Muhammad, A. (2011). Effect of Entrepreneur and Firm Characteristics on the Business Success of Small and Medium Enterprises (SMEs) in Bangaldesh. Intemational Joumal of Business and Management, 6(3), 289-299.

Kipp, J. (2010). Optimal Climate Regions in Mexico for Greenhouse Crop Production. Wageningen UR Greenhouse Horticulture, Bleiswijk, The Netherlands, 1-24.

Lee, H., Kelley, D., Lee, J., \& Lee, S. (2012). Sme Survival: The Impact of Internationalization, Technology Resources, and Alliances. Small Business Management, 50(1), 1-19. http://dx.doi.org/10.1111/j.1540-627X.2011.00341.x

Lussier, R., \& Halabi, C. (2010). A Three-Country Comparison of the Business. Journal of Small Business Management, 48(3), 360-377. http://dx.doi.org/10.1111/j.1540-627X.2010.00298.x 
Lussier, R., \& Pfeifer, S. (2001). A Crossnational Prediction Model for Business Success. Journal of Small Bussiness Management, 39(3), 228-239. http://dx.doi.org/10.1111/0447-2778.00021

Mahmood, J., \& Asif, M. I. (2011). Determinants of Business Success of Small and Medium Enterprises. International Journal of Business and Social Science, 2(20), 274-280.

Manzano, F., \& García, A. (2009). Técnicas de Estudio de Tiempos para la Planificación del a Mano de Obra en el Cultivo de Tomate de Invernadero. Agrociencia, 43(3), 267-277.

Newbert, S. L., Gopalakrishnan, S., \& Kirchhoff, B. A. (2008). Looking beyond resources: Exploring the importance of entrepreneurship to firm-level competitive advantage in technologically intensive industries. Technovation, 28(1-2), 6-19. http://dx.doi.org/10.1016/j.technovation.2007.07.002

Observatorio PyME. (2002). Retrieved November 6, 2011, from http://i2.esmas.com/documents/2009/08/26/107/estadisticas-pymes.pdf

Ortega, D., Sánchez, J., Ocampo, J., Sandoval, E., Salcido, B., \& Manzo, F. (2010). Efecto de Diferentes Sustratos en Crecimiento y Rendimiento de Tomate. Ra Ximhai, 6(3), 339-346.

Puerto, D. P. (2010). La Globalización y el Crecimiento Empresarial a través de Estrategias de Internacionalización. Pensamiento y Gestión, 28(ene-jun), 171-195.

Reséndiz, M., Aguilar, J., \& Luévano, A. (2011). Características de la Agricultura Protegida y su Entorno en México. Revista Mexicana de Agronegocios, 15(29), 763-774.

Resvani, M., Gilaninia, S., Mousavian, S., \& Shahraki, M. (2011). Studying the Impact of Government Support on Sme Cooperative Companies Financial Status. Australian Journal of Basic and Applied Sciences, 5(6), 1309-1314.

Ríos, S., \& García, R. (2011). Las ayudas agroambientales a la Ganadería Orgánica en Andalucía como Motor de Desarrollo. Un Análisis desde la Percepción de los Actores. Revista Lider, 18(13), 155-165.

Rockart, J. F. (1982). The Changing Role of the Information Systems Executive: A Critical Success Factors Perspective. Sloan Management Review, 85, 3-13.

Secretaría de Desarrollo Agropecuario. (2010). Anuario Estadístico del Sector Rural. Querétaro: Oficina Estatal de Información para el Desarrollo Rural Sustentable del Estado de Querétaroo.

Secretaria de Economía. (2011). Secretaría de Economía. Retrieved November 18, 2011, from http://www.economia.gob.mx/index.php/component/content/article/186-pymes/6822-las-pymes-y-su-papel-en-e 1-desarrollo-de-la-economia-de-mexico

Simpson, M., Tuck, N., \& Bellamy, S. (2004). Small Business Success Factors: The Role of Education and Training. Education + Training, 46(8/9), 481-491. http://dx.doi.org/10.1108/00400910410569605

Urrestarazu, M., Castillo, J., \& Salas, M. (2002). Técnicas Culturales y Calidad del Pimiento. Horticultura, 18-26.

Van Praag, M. (2003). Business Survival and Success of Young Small Business Owners. Small Business Economics, 21(1), 1-17. http://dx.doi.org/10.2139/ssrn.289202

Vivanco, J., Aguilera, L., \& González, M. (2011). Desarrollo de las Pymes con base en la Adopción de Estrategias Financieras en Aguascalientes. Retrieved November 18, 2011, from http://congreso.investiga.fca.unam.mx/docs/anteriores/xvi/docs/1G.pdf

Yin, R. K. (1994). Case Study Research. Design and Methods. California, USA.: SAGE Publicaciones, Inc. 